\title{
Elevated Serum Levels of Homocysteine as an Early Prognostic Factor of Psychiatric Disorders in Children and Adolescents
}

\author{
Laura Kevere, ${ }^{1}$ Santa Purvina, ${ }^{2}$ Daiga Bauze, ${ }^{3}$ Marcis Zeibarts, ${ }^{2}$ Raisa Andrezina, ${ }^{1}$ \\ Arnis Rizevs, ${ }^{3}$ Sergejs Jelisejevs, ${ }^{3}$ Linda Piekuse, ${ }^{4}$ Madara Kreile, ${ }^{4}$ and Indulis Purvins ${ }^{2}$ \\ ${ }^{1}$ Department of Psychiatry and Narcology, Riga Stradins University, 215-27 Maskavas Street, 1019 Riga, Latvia \\ ${ }^{2}$ Department of Internal Diseases, Riga Stradins University (RSU), 13 Pilsonu Street, 1002 Riga, Latvia \\ ${ }^{3}$ Children's Psychiatric Hospital BKUS “Gailezers", 20 Juglas Street, 1079 Riga, Latvia \\ ${ }^{4}$ Scientific Laboratory of Molecular Genetics, Riga Stradins University, 16 Dzirciema Street, 1007 Riga, Latvia \\ Correspondence should be addressed to Laura Kevere, kevere@gmail.com
}

Received 21 March 2012; Revised 27 July 2012; Accepted 13 August 2012

Academic Editor: David C. Henderson

Copyright (C) 2012 Laura Kevere et al. This is an open access article distributed under the Creative Commons Attribution License, which permits unrestricted use, distribution, and reproduction in any medium, provided the original work is properly cited.

\begin{abstract}
Background and Goal. The aim was to examine the serum levels of homocysteine (Hcy) and their associations with the methylenetetrahydrofolate reductase (MTHFR) gene C677T polymorphism in patients with schizophrenia and mood disorders as well as controls. Materials and Methods. There were 198 patients: 82 with schizophrenia spectrum disorders, 22 with mood disorders, and 94 controls. The level of Hcy was determined by an isocratic high-performance liquid chromatography system. MTHFR C677T polymorphism was analysed using the restriction fragment length polymorphism-polymerase chain reaction method. Results. The average level of Hcy was $11.94 \pm 5.6 \mu \mathrm{mol} / \mathrm{L}$ for patients with schizophrenia, $11.65 \pm 3.3 \mu \mathrm{mol} / \mathrm{L}$ for patients with affective disorders, versus $6.80 \pm 2.93 \mu \mathrm{mol} / \mathrm{L}$ in a control. The highest level of Hcy has been observed in patients with episodicrecurrent course of schizophrenia $(11.30 \pm 7.74 \mu \mathrm{mol} / \mathrm{L})$, paranoid schizophrenia continuous $(12.76 \pm 5.25 \mu \mathrm{mol} / \mathrm{L})$, and in patients with affective disorders $(11.65 \pm 3.26 \mu \mathrm{mol} / \mathrm{L})$. An association between the MTHFR gene C677T polymorphism and Hcy level was found by linear regression analysis $(r=1.41, P=0.029)$. Conclusions. The data indicate a link between Hcy levels and schizophrenia and mood disorders. No associations between the level of Hcy in patients with schizophrenia and mood disorders and the MTHFR C677T polymorphism were found.
\end{abstract}

\section{Introduction}

Hcy was first described by Butz and du Vigneud in 1932 [1]. They obtained the product by treating methionine with a concentrated acid.

Three enzymes are directly involved in the Hcy metabolism: methionine synthase (MS), betaine homocysteine methyltransferase, and cystathionine $\beta$-synthase. Several other enzymes are indirectly involved. Vitamins $B_{6}$ and $B_{12}$ are cofactors to these enzymes, and folate is a substrate in the MS-mediated reaction [2]. Deficiencies in vitamins $B_{6}, B_{12}$, and folate can lead to high Hcy levels. Supplementation with pyridoxine, folic acid, $\mathrm{B}_{12}$, or folic acid, respectively, reduces the concentration of Hcy in the bloodstream.

Methionine is the immediate precursor of S-adenosylmethionine, the methyl donor of numerous methylation reactions in the brain, including many that are directly involved in the synthesis and metabolism of monoamines such as dopamine, norepinephrine, and serotonin [3]. This suggests that an association between elevated Hcy and schizophrenia is biologically plausible.

Another way of investigating the association between Hcy and mental disorders is via the MTHFR gene. MTHFR converts 5,10-methylenetetrahydrofolate to 5-methyltetrahydrofolate, which is needed for the remethylation of Hcy to methionine [4].

MTHFR is a critical component of the 1-carbon cycle, and MTHFR gene C677T polymorphism affects nucleotide synthesis and DNA methylation. This gives a plausible biological explanation for potential associations between genetic variation in folate metabolism and both depression and schizophrenia [5]. 
Previous findings indicate that the risk of suffering from psychiatric illness is correlated with elevated levels of Hcy [6]. Men with MTHFR gene C677T polymorphism are at greater risk of schizophrenia than women; women are at greater risk of bipolar affective disorders (BADs) [7].

Elevated Hcy is associated with an increased risk of occlusive vascular disease, birth defects (neural tube defects), complications during pregnancy, and psychiatric disorders (major unipolar depression, anxiety disorders, BADs, and in a gender-specific manner, schizophrenia) [8].

A high level of prenatal Hcy is a valid risk factor for schizophrenia and affective disorders, because Hcy is a partial antagonist of $\mathrm{N}$-methyl-D-aspartate (NMDA) receptors. This antagonism can lead to the dysfunction of NMDA receptors in these patients. It is associated with changes in glycine concentration, which result in disturbances of the functioning of the placenta and pregnancy complications [2].

Hcy influences the foetus in the early stages, through disordered brain structure development and function, and/or through placenta vascularization disorders, which reduces the oxygen feed to the foetus [2].

Hcy and Hcy-acid have the ability to increase intracellular calcium levels of ions and active oxygen compounds within the cerebellum of rats as NMDA. NMDA rouses premature apoptosis of cells. These mechanisms indicate the neurotoxic impact of Hcy and its derivatives [9].

Previous studies indicate that elevated Hcy presents conditions of stress in wefts, followed by an increase in the permeability of the haematoencephalic barrier for neurotoxic materials $[10,11]$. Other reports show that young men with BADs have a much higher level of Hcy than healthy people. Hcy is highest in those with more severe BAD diagnoses. Hcy may be elevated for women in all age groups but is not as high as it is for men [12-14]. Based on these results, another study found a possible association between BAD and schizophrenia with the 1p36.3 MTHFR locus [15]. Deterioration of clinical symptoms is observed as a result, and neurodegenerative occurrences tend to become chronic.

Based on these findings, it is important to establish which mental disorders are linked with changes of Hcy levels in blood plasma, and whether the changes in Hcy concentration depend on a clinical state of mental disorder (e.g., whether the disorder is in the early, middle, or late stage of progression, or in remission).

The aim of our study was to examine the serum levels of Hcy and determine whether they may be linked to MTHFR gene polymorphism and increased frequency of the TT genotype in patients with schizophrenia and affective spectrum disorders, compared with controls. We also sought to determine the clinical specificity of these disorders.

\section{Materials and Methods}

The investigation was carried out in the Department of Pharmacology at Riga Stradinšs University (RSU), Latvia, and in the Riga's Children's Psychiatric Hospital. All patients signed an informed consent form (for children, consent was given by one parent), issued accordance with RSU Medical Ethics Committee requirements.
One hundred and four patients from the Children's Psychiatric Hospital participated in the study. Patients were divided into four diagnostic groups, based on ICD-10 diagnostic criteria (ICD-10 Classification of Mental and Behavioural Disorders: Diagnostic Criteria for Research) [16] and their current health. Each diagnosis and clinical status was coded according to its severity and the course of the disease. The groups were classified as follows: group $1(n=18)$, paranoid schizophrenia (continuous); group 2 ( $n=37$ ), paranoid schizophrenia (episodic with residual symptoms); group $3(n=27)$, simple schizophrenia; group 4 ( $n=22$ ), affective spectrum disorders (depressive episode, recurrent depressive disorders with or without associated anxiety); group $5(n=94)$, control group of children and adolescents (healthy) (Table 1).

Healthy children, aged 3-17, were selected from kindergartens and high schools for the control group. A wide age range was used because while the parents of most of the younger children consented to blood biochemical and genetic analyses being performed, the majority of the parents of the teenagers and the teenagers themselves did not agree to such analyses. This refusal appears to be related to the fear and stigma of a prognostic genetic or mental illness being diagnosed.

Demographic characteristics of the patient groups are described in Table 2. Patients with severe somatic pathology (e.g., renal insufficiency, usage of glucocorticoids), evidence of genetic disease, and those who did not consent to participate, or whose parents or guardians refused consent, were not included in the study.

The patients' treatment regimen, designated by their attending physician, was not changed. Medications were administered in accordance with the set indications and dosing principles, including the evaluation of both contraindications and possible side effects.

The data were registered in a special form and included information about family anamnesis, childhood, the onset of the disease, its process and individuality, all previous therapies and their results, and the current treatment and its effectiveness.

The levels of vitamin $\mathrm{B}_{12}$ and folic acid in the blood were analysed in the Laboratory of Nacionalais Medicinas Serviss (NMS). The level of Hcy in the blood was analysed in the Research Laboratory of Pharmacology Department of RSU with an isocratic high-performance liquid chromatography (HPLC) system with fluorometric detection (Shimadzu LC20 , model $R F-10 A x L$ ). Sample preparation and chromatographic separation were performed in accordance with the recommendations of the commercially available Chromsystems $\mathrm{GmbH}$ (Germany) kit for HPLC analyses of Hcy in plasma.

The reduction step for releasing Hcy from its proteinbound state, protein precipitation, and precolumn derivatization followed by HPLC separation and fluorescent detection is the most widely applied technique [4].

During the research, none of the patients took vitamins-neither dietary supplements nor vitamin preparations. All samples were taken early in the morning on an empty stomach. 
TABLE 1: Clinical characteristic of patients groups [17-19].

\begin{tabular}{|c|c|c|c|c|c|c|}
\hline & Development & Clinical characteristic & $\begin{array}{l}\text { Affective } \\
\text { disorders }\end{array}$ & Cognitive disorders & Therapy & Prognosis \\
\hline $\begin{array}{l}\text { Continuous } \\
\text { course Sch }\end{array}$ & Gradual & $\begin{array}{l}\text { Relatively stable, often } \\
\text { paranoid delusions, usually } \\
\text { accompanied by } \\
\text { hallucinations, particularly } \\
\text { of the auditory variety, and } \\
\text { perceptual disturbances. } \\
\text { Volition and speech, and } \\
\text { catatonic symptoms are } \\
\text { either absent or relatively } \\
\text { inconspicuous }\end{array}$ & $\begin{array}{l}\text { Disturbances of } \\
\text { affect. Affects } \\
\text { that are } \\
\text { inappropriate or } \\
\text { blunted }\end{array}$ & $\begin{array}{l}\text { Clear } \\
\text { consciousness and } \\
\text { intellectual } \\
\text { capacity are usually } \\
\text { maintained } \\
\text { although certain } \\
\text { cognitive deficits } \\
\text { may evolve in the } \\
\text { course of time }\end{array}$ & $\begin{array}{l}\text { Often lasting } \\
\text { usage of several } \\
\text { antipsychotic } \\
\text { medicine }\end{array}$ & $\begin{array}{l}\text { Bad, progressing } \\
\text { course with defect } \\
\text { becoming deeper, } \\
\text { resistance of } \\
\text { therapy, disability }\end{array}$ \\
\hline $\begin{array}{l}\text { Episodic } \\
\text { course Sch }\end{array}$ & Acute & $\begin{array}{l}\text { Episodic with progressive } \\
\text { or stable deficit, in the } \\
\text { periods of exacerbation of } \\
\text { disease symptoms like a } \\
\text { continuous course Sch }\end{array}$ & Anxiety, fears & $\begin{array}{l}\text { Early onset-have } \\
\text { more significant } \\
\text { deficits in } \\
\text { measures of IQ, } \\
\text { memory, and tests } \\
\text { of perceptuomotor } \\
\text { skills. Disturbances } \\
\text { of working } \\
\text { memory and } \\
\text { attention }\end{array}$ & $\begin{array}{l}\text { Aggravation } \\
\text { therapy- } \\
\text { commonly } 2 \\
\text { antipsychotic } \\
\text { medicaments, } \\
\text { remissions- } \\
\text { monotherapy }\end{array}$ & $\begin{array}{l}\text { Bad, progressing } \\
\text { course with defect } \\
\text { becoming deeper, } \\
\text { resistance of } \\
\text { therapy, disability }\end{array}$ \\
\hline $\begin{array}{l}\text { Simple } \\
\text { schizophrenia }\end{array}$ & Gradual & $\begin{array}{l}\text { Simple schizophrenia is } \\
\text { characterised with an } \\
\text { insidious but progressive } \\
\text { development of oddities of } \\
\text { conduct, inability to meet } \\
\text { the demands of society, and } \\
\text { decline in total } \\
\text { performance. The } \\
\text { characteristic negative } \\
\text { features of residual } \\
\text { schizophrenia develop } \\
\text { without being preceded by } \\
\text { any overt psychotic } \\
\text { symptoms }\end{array}$ & $\begin{array}{l}\text { Cold or } \\
\text { inappropriate } \\
\text { affect, blunting } \\
\text { of affect, and } \\
\text { loss of volition }\end{array}$ & $\begin{array}{l}\text { Early onset-have } \\
\text { more significant } \\
\text { deficits in } \\
\text { measures of IQ, } \\
\text { memory, and tests } \\
\text { of perceptuomotor } \\
\text { skills. Disturbances } \\
\text { of working } \\
\text { memory and } \\
\text { attention }\end{array}$ & $\begin{array}{l}\text { DRAs } \\
\text { monotherapy, } \\
\text { often } \\
\text { combinations } \\
\text { with AEDs }\end{array}$ & $\begin{array}{l}\text { Bad. Gradual } \\
\text { inellectual skills } \downarrow \text {, } \\
\text { emotional } \\
\text { disorders, } \\
\text { formation of } \\
\text { identity defect }\end{array}$ \\
\hline $\begin{array}{l}\text { Affective } \\
\text { disorders- } \\
\text { depressive } \\
\text { episode, } \\
\text { recurrent } \\
\text { depressive } \\
\text { disorders } \\
\text { (with or } \\
\text { without } \\
\text { associated } \\
\text { anxiety) }\end{array}$ & $\begin{array}{l}\text { Subacute/ } \\
\text { acute }\end{array}$ & $\begin{array}{l}\text { Depression-the patient suff } \\
\text { lowering of mood, reduction } \\
\text { and decrease in activity. Capa } \\
\text { enjoyment, interest, and mar } \\
\text { tiredness after even minimun } \\
\text { common. Sleep is usually dis } \\
\text { and appetite diminished. Self } \\
\text { and self-confidence are almo } \\
\text { reduced, and, even in the mil } \\
\text { some ideas of guilt or worthl } \\
\text { are often present. The lowere } \\
\text { varies little from day to day, } \\
\text { unresponsive to circumstance } \\
\text { may be accompanied by the s } \\
\text { "somatic" symptoms, such as } \\
\text { interest and pleasurable feelir } \\
\text { waking in the morning sever } \\
\text { before the usual time, depres } \\
\text { in the morning, marked psyc } \\
\text { retardation, agitation, loss of } \\
\text { weight loss, and loss of libido }\end{array}$ & $\begin{array}{l}\text { ors from } \\
\text { of energy, } \\
\text { acity for } \\
\text { ked } \\
\text { n effort is } \\
\text { turbed } \\
\text { f-esteem } \\
\text { st always } \\
\text { ld form, } \\
\text { essness } \\
\text { d mood } \\
\text { is } \\
\text { es, and } \\
\text { so-called } \\
\text { s loss of } \\
\text { ngs, } \\
\text { al hours } \\
\text { sion worst } \\
\text { homotor } \\
\text { appetite, } \\
\text { a }\end{array}$ & $\begin{array}{l}\text { Hard to } \\
\text { concentrate, slow } \\
\text { thinking rate }\end{array}$ & $\begin{array}{l}\text { Antidepressant } \\
\pm \text { AEDs }\end{array}$ & $\begin{array}{l}\text { Good, in case of } \\
\text { duly treatment }\end{array}$ \\
\hline
\end{tabular}


TABle 2: Demographic characteristics of patients groups.

\begin{tabular}{lccc}
\hline & Schizophrenia & $\begin{array}{c}\text { Affective } \\
\text { disorders }\end{array}$ & $\begin{array}{c}\text { Control } \\
\text { group }\end{array}$ \\
\hline Gender & $50(61 \%)$ & $6(27 \%)$ & $54(57 \%)$ \\
$\quad$ Male & $32(39 \%)$ & $16(33 \%)$ & $40(43 \%)$ \\
Female & & & \\
Age (years) & 0 & 0 & $34(36 \%)$ \\
$3-7$ & $12(15 \%)$ & $5(23 \%)$ & $26(28 \%)$ \\
$7-12$ & $23(28 \%)$ & $6(27 \%)$ & $12(13 \%)$ \\
$12-15$ & $47(57 \%)$ & $11(50 \%)$ & $22(23 \%)$ \\
$15-18$ & & & \\
Duration of illness (years) & $37(45 \%)$ & $11(50 \%)$ & 0 \\
1 & $24(29 \%)$ & $8(36 \%)$ & 0 \\
$2-3$ & $21(26 \%)$ & $3(14 \%)$ & 0 \\
$>3$ & 0 & 0 & $94(100 \%)$ \\
$\quad$ No illness & & &
\end{tabular}

Genetic studies involving DNA isolations were performed in the RSU Scientific Laboratory of Molecular Genetics. The standard phenol-chloroform method was used to isolate DNA from venous blood [20]. MTHFR C677T (rs1801133) polymorphism was analysed by the restriction fragment length polymorphism-polymerase chain reaction (RFLP-PCR) analyses adapted method [17]. PCR was performed in a total volume of $20 \mu \mathrm{L}$, containing $2 \mu \mathrm{L} 10 \times$ Taq buffer with $\left(\mathrm{NH}_{4}\right)_{2} \mathrm{SO}_{4}$ (Fermentas), $1.6 \mu \mathrm{L} 25 \mathrm{mM} \mathrm{MgCl}_{2}$, $0.5 \mu \mathrm{L} 10 \mathrm{mM}$ dNTP, $2.5 \mathrm{U}$ recombinant Taq polymerase (Fermentas), and $5 \mu \mathrm{L}$ of the following $10 \mathrm{pmol} / \mu \mathrm{L}$ primers: MTHFR-PF 5'TGAAGGAGAAAGGTGTCTGCGGGA3' and MTHFR-P5' AGGACGGTGCGGTGAGAGTG3'. The reaction was carried out in a TProfessional Thermocycler (Biometra). Following denaturation at $95^{\circ} \mathrm{C}$ for $3 \mathrm{~min}, 30$ cycles at $94^{\circ} \mathrm{C}, 65^{\circ} \mathrm{C}$, and $72^{\circ} \mathrm{C}$ for 1 min each were performed. A final extension step at $72^{\circ} \mathrm{C}$ for 10 min concluded the reaction. The 198-bp PCR product $(4 \mu \mathrm{L})$ was digested with restriction enzyme Hinfl (Fermentas) at $37^{\circ} \mathrm{C}$ for $18 \mathrm{~h}$. HinfI can recognize the cytosine to thymine substitution and formed $176 \mathrm{bp}$ and $22 \mathrm{bp}$ long fragments. The HinfItreated PCR fragments were analysed by $6 \%$ polyacrylamide gel electrophoresis at $180 \mathrm{~V}$ for $40 \mathrm{~min}$, stained with ethidium bromide, and visualized under UV light. Direct sequencing (ABI Prism 300 Genetic analyser, using Big Dye v.3.1. kit (Applied Biosystems)) was used for some of the DNA samples. In all cases, genotypes corresponded to those after RFLP analysis.

\section{Statistical Analysis}

Several methods and statistical indicators were used for data analysis: mean value, average standard deviation, and average standard errors.

The validity of the difference between the average measurements of the two groups was estimated with the Student's $t$-test, with $P<0.05$ set as the significance level.
TABle 3: Correlation $(r)$ of Hcy concentration between control group and psychiatric disorder groups.

\begin{tabular}{lcc}
\hline \multirow{2}{*}{ Diagnosis } & \multicolumn{2}{c}{ Control group } \\
& $\begin{array}{c}\text { Pearson's } \\
\text { correlation }\end{array}$ & $t$ test \\
\hline Schizophrenia spectrum disorders & -.46 & $<0.01$ \\
Paranoid schizophrenia, continuous & -.58 & $<0.01$ \\
Paranoid schizophrenia, episodic with & -.56 & $<0.01$ \\
residual symptoms & -.19 & $<0.01$ \\
Simple schizophrenia & -.45 & $<0.01$ \\
\hline
\end{tabular}

The $t$-test is used to evaluate the differences in means between two groups. Pearson correlation coefficient $r$, also called linear or product-moment correlation, is used to determine the extent to which values of two variables are "proportional" to each other.

The data were analysed using the following Stata data analysis tools: regression statistics, two-sample $t$-test with equal variances, Bartlett's test for equal variances, the and Bonferroni test. Pearson correlation coefficient $r$, also called linear or product-moment correlation, was used to determine the extent to which values of two variables were "proportional" to each other.

\section{Results}

Vitamin $B_{12}$ and folic acid levels were found to be within the normal ranges for all patients. The correlation of Hcy concentration between the control group and psychiatric disorders is described in Table 3.

It has been found out that the highest level of Hcy in the group of schizophrenia spectrum disorders was observed in patients with paranoid schizophrenia-continuous (12.76 $\pm 5.25 \mu \mathrm{mol} / \mathrm{L})$ and episodic-recurrent process of disease $(11.30 \pm 7.75 \mu \mathrm{mol} / \mathrm{L})(r=-0.56 ; P<0.01)$. For the group with the affective disorders, the highest level was observed in patients with depressive symptoms of anxiety and patients with mixed affective disorders $(r=-0.58$; $P<0.01)$. The lowest level of Hcy was observed in patients with simple schizophrenia and depression without anxiety $(8.47 \pm 3.26 \mu \mathrm{mol} / \mathrm{L}$ and $9.25 \mu \mathrm{mol} / \mathrm{L}$, resp.) (Figure 1).

In the genetic analysis, patients were divided into three groups, depending on the existing genotype for the T allele: CC (healthy), CT (heterozygous), and TT (homozygous). Genetic analysis was completed for 180 patients: 80 patients had the CC genotype, 92 patients had the CT genotype, and only eight had the TT genotype. No genotype prevalence was observed in either of the studied patient groups $(P<$ 0.01). An association between the MTHFR gene C677T polymorphism and Hcy level was found by linear regression analysis $(r=1.41, P=0.029)$.

\section{Discussion}

Research studies have not yet convincingly demonstrated the role of Hcy in the pathogenesis of mental disorders. The findings reflect partial, episodic, and sometimes even 


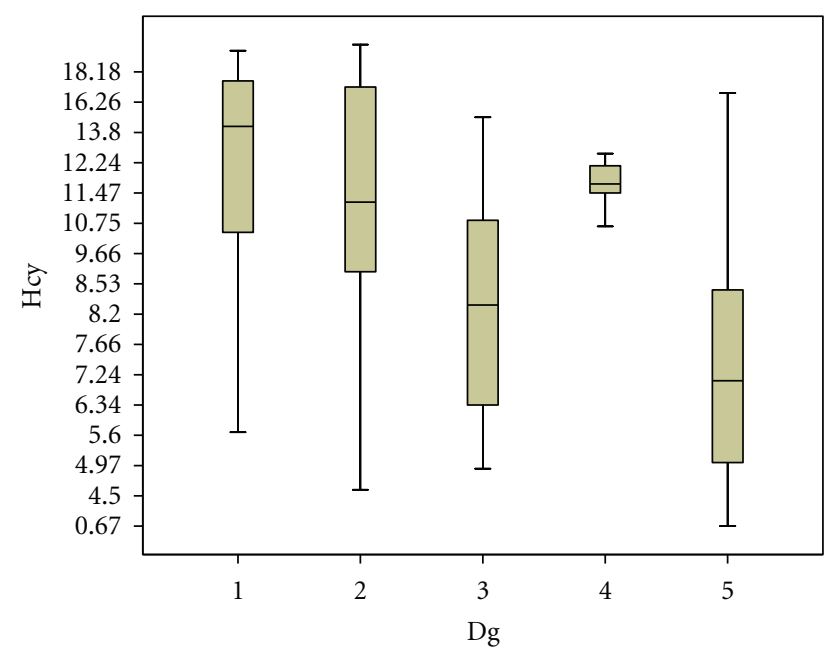

Codes of diagnosis (Dg):

1- paranoid schizophrenia, continuous

2- paranoid schizophrenia, episodic with residual symptoms

3- simple schizophrenia

4- depressive episode, recurrent depressive disorder

5- control group (healthy)

Figure 1: The mean level of Hcy ( $\mu \mathrm{mol} / \mathrm{L})$ in patients with affective disorders and schizophrenia spectrum disorders.

weak clinical correlations between hyperhomocysteinemia and psychiatric disease. Replications of studies do not always support this correlation.

If schizophrenia begins before the age of 12 , it is called juvenile schizophrenia. It occurs in one out of 10,000 children, but the incidence of schizophrenia and schizophrenia-related disorders rises to 1-2 out of 1000 in adolescents [21]. The fact that schizophrenia may present before puberty suggests that the cause of the disease may be a neurodevelopmental abnormality [18].

When the onset of schizophrenia occurs in childhood, it is commonly observed that the child's relatives are also likely to have a form of schizophrenia, even though they may not be diagnosed until adulthood [19].

Premature onset is more common for men and predominates between the ages of 11 and 14 . Women most frequently become ill after puberty. Therefore, men more frequently have the continuous form of schizophrenia, while women are more likely to have an episodic remitting form, with affective disorders in the acute stage of the disorder. This is consistent with the fact that the process of schizophrenia is different in different age groups: younger children typically have continuous slowly progressive schizophrenia, while older children (prepubescent and pubescent) tend to have an episodic remitting course [22, 23]. More boys than girls have schizophrenia, particularly at younger ages $[22,23]$. In our study, it was observed that the boys had the illness earlier and that very often the progress of the illness was continuous, whereas the girls become ill later and the progress of the illness was more often characterized by episodic intensifications and remissions. When schizophrenia occurs in childhood or adolescence, the manifestations of prodrome-development disorders or social functioning disorders - can almost always be observed. Disorders of the nervous system generate speech and language development disorders, as well as awkwardness, inattentiveness, and demoted IQ level (usually around 90) [24]. More specific cognitive deficiencies, including a decline in working memory and disorders of attention concentration, are observed in early schizophrenia [24].

Affective disorders are common in those clinically diagnosed with schizoaffective disorders, episodic schizophrenia, and continued paranoid schizophrenia.

It has been established that increased Hcy levels are commonly linked with the MTHFR gene TT genotype. This results in brain development disorders; the brain becomes increasingly sensitive to exotoxin, which creates a predisposition for later schizophrenia development [25]. This theory is supported by the fact that elevated Hcy levels during pregnancy are considered to be a risk factor for nervous tube development anomalies.

The MTHFR gene is located at the end of the short arm of chromosome 1 (1p36.3). Methylenetetrahydrofolate reductase plays a central role in folate metabolism by irreversibly converting 5,10-methylenetetrahydrofolate to 5-methylenetetrahydrofolate, the predominant circulating form of folate. 5-methylenetetrahydrofolate donates a methyl group to Hcy in the generation of S-adenosylmethionine, a major source of methyl groups in the brain [25].

Two common single MTHFR nucleotide polymorphisms have been reported: a $\mathrm{C} \rightarrow \mathrm{T}$ transition at nucleotide 766 in exon 4 (rs1801133) and an $\mathrm{A} \rightarrow \mathrm{C}$ transversion in exon 7 at position 1298 (rs1801131). Both of these polymorphisms are functional and result in diminished enzyme activity. For the C677T polymorphism, homozygote variants have $30 \%$ more enzyme activity than homozygotes for the wild-type $\mathrm{C}$ allele, while heterozygotes retain $65 \%$ of wild-type MTHFR enzyme activity [26]. The consequences of the C677T polymorphism have been demonstrated in population studies, where lower levels of red blood cell folate, plasma folate, and vitamin $B_{12}$ have been reported among healthy persons with genotype $677 \mathrm{TT}$ as well as among persons with other genotypes [26].

There was an increased risk of schizophrenia among homozygote variants (TT) in one study, although the reliability of the statistical data was low [27]. Subjects with schizophrenia showed a significantly increased frequency of the $\mathrm{T}$ allele. A cumulative meta-analysis showed that a moderate and significant association between schizophrenia and MTHFR C677T remained over time. However, no association between MTHFR C677T and anxiety disorders was found [28].

To date, no studies have linked hyperhomocysteinemia with psychiatric disorders in children and adolescents. Some studies have explored the associations between Hcy level and schizophrenia in adolescents by using numerically small groups of patients (aged 14-21 years). It is clear that Hcy level is higher in patients with schizophrenia than in healthy control-group patients; however, this concurrence has been observed only in boys [28]. 
In our study, significantly higher levels of Hcy were observed during the onset and exacerbation of the disease. This leads us to suggest that there is no relationship between Hcy and schizophrenia spectrum disorders per se but that a relationship exists between Hcy and the current affective state, in respect to the basic diagnosis.

In our study, no relationship was found between MTHFR gene homozygous (TT) or heterozygous (CT) genotype variants and any form of schizophrenia. Similarly, no role of the TT genotype in the elevated level of Hcy was observed.

\section{Conclusions}

Our data clearly indicate a potential link between the levels of Hcy and psychiatric disorders (schizophrenia and mood disorders). It can be concluded that the increased level of Hcy in schizophrenia and mood disorders is associated with affect and the course of the disease. Therefore, the results support the hypothesis that Hcy may be one of the risk factors of schizophrenia and mood disorders.

The data do not suggest a more frequent occurrence of any MTHFR gene C677T genotype (CC, CT, or TT) for any form of schizophrenia or mood disorder. Nevertheless, the collection of more precise genetic data, from a larger number of patients, is desirable.

\section{Conflict of Interests}

The authors declare that they have no competing interests and did not apply for or receive any funding for this work.

\section{References}

[1] J. D. Finkalstein, "Homocysteine: a history in progress," Nutrition Reviews, vol. 58, pp. 193-204, 2000.

[2] C. Bolander-Gouaille and T. Bottiglieri, Homocysteine Related Vitamins and Neuropsychiatric Disorders, Springer, Paris, France, 2nd edition, 2007.

[3] T. Bottiglieri, M. Laundy, R. Crellin, B. K. Toone, M. W. P. Carney, and E. H. Reynolds, "Homocysteine, folate, methylation, and monoamine metabolism in depression," Journal of Neurology Neurosurgery and Psychiatry, vol. 69, no. 2, pp. 228232, 2000.

[4] M. Klerk, P. Verhoef, R. Clarke, H. J. Blom, F. J. Kok, and E. G. Schouten, "MTHFR $677 \mathrm{C} \rightarrow \mathrm{T}$ polymorphism and risk of coronary heart disease: a meta-analysis," Journal of the American Medical Association, vol. 288, no. 16, pp. 2023-2031, 2002.

[5] A. Coppen and C. Bolander-Gouaille, "Treatment of depression: time to consider folic acid and vitamin B 12," Journal of Psychopharmacology, vol. 19, no. 1, pp. 59-65, 2005.

[6] J. W. Muntjewerff, R. S. Kahn, H. J. Blom, and M. Den Heijer, "Homocysteine, methylenetetrahydrofolate reductase and risk of schizophrenia: a meta-analysis," Molecular Psychiatry, vol. 11, no. 2, pp. 143-149, 2006.

[7] B. Kempisty, A. Bober, M. Łuczak et al., "Distribution of 1298A > C polymorphism of methylenetetrahydrofolate reductase gene in patients with bipolar disorder and schizophrenia," European Psychiatry, vol. 22, no. 1, pp. 39-43, 2007.

[8] C. J. Murray and A. D. Lopez, The Global Burden of Disease: A Comprehensive Assessment of Mortality and Disability from
Disease, Injuries and Risk Factors in 1990, Harvard School of Publics Health, Boston, Mass, USA, 1996.

[9] A. S. Brown, T. Bottiglieri, C. A. Schaefer et al., "Elevated prenatal homocysteine levels as a risk factor for schizophrenia," Archives of General Psychiatry, vol. 64, no. 1, pp. 31-39, 2007.

[10] A. V. Makhro, E. R. Bulygina, and A. A. Boldyrev, "Effects of homocysteine and homocysteinic acid on cerebellar granule cells," Neurochemical Journal, vol. 1, no. 2, pp. 127-132, 2007.

[11] S. A. Lipton, W. K. Kim, Y. B. Choi et al., "Neurotoxicity associated with dual actions of homocysteine at the N-methylD-aspartate receptor," Proceedings of the National Academy of Sciences of the United States of America, vol. 94, no. 11, pp. 5923-5928, 1997.

[12] A. Friedman, D. Kaufer, J. Shemer, I. Hendler, H. Soreq, and I. Tur-Kaspa, "Pyridostigmine brain penetration under stress enhances neuronal excitability and induces early immediate transcriptional response," Nature Medicine, vol. 2, no. 12, pp. 1382-1385, 1996.

[13] J. Levine, B. A. Sela, Y. Osher, and R. H. Belmaker, "High homocysteine serum levels in young male schizophrenia and bipolar patients and in an animal model," Progress in NeuroPsychopharmacology and Biological Psychiatry, vol. 29, no. 7, pp. 1181-1191, 2005.

[14] L. J. Ninger, "Homocysteine as a Risk Factor for Disease. Life Extension Magazine," 2006, http://www.lef.org/magazine/ mag2006/oct2006_report_risk_01.htm.

[15] Y. Osher, B. A. Sela, J. Levine, and R. H. Belmaker, "Elevated homocysteine levels in euthymic bipolar disorder patients showing functional deterioration," Bipolar Disorders, vol. 6, no. 1, pp. 82-86, 2004.

[16] ICD-10 Classification of Mental and Behavioural Disorders: Diagnostic Criteria for Research, http://www.who.int/classifications/icd/en/GRNBOOK.pdf.

[17] C. Marinho, I. Alho, D. Arduíno, L. M. Falcão, J. BrásNogueira, and M. Bicho, "GST M1/T1 and MTHFR polymorphisms as risk factors for hypertension," Biochemical and Biophysical Research Communications, vol. 353, no. 2, pp. 344350, 2007.

[18] A. Grieco, "Homocystinuria: pathogenetic mecanisms," American Journal of the Medical Sciences, vol. 273, no. 2, pp. 120$132,1977$.

[19] V. V. Kovalev, Psychiatry of Childhood, Medicina, Moscow, Russia, 1979.

[20] F. M. Ausubel, Current Protocols in Molecular Biology, New Yourk, NY, USA, 1st edition, 1987.

[21] B. J. Sadock and V. A. Sadock, Synopsis of Psychiatry, Lippincott Williams \& Wilkins, Philadelphia, Pa, USA, 10th edition, 2007.

[22] A. S. Tiganov, Manual of Psychiatry, vol. 1, Medicina, Moscow, Russia, 1999.

[23] R. Goodman and S. Scott, Child Psychiatry, Blackwell Science, 1997.

[24] G. L. Cantoni, "S-Anenysylmethionine: a new intermediate formed enzymatically from 1 -methionine and adenosine triphosphate," Journal of Biological Chemistry, vol. 204, pp. 403-416, 1953.

[25] R. Rozen, "Molecular genetics of methylenetetrahydrofolate reductase deficiency," Journal of Inherited Metabolic Disease, vol. 19, no. 5, pp. 589-594, 1996.

[26] A. M. Molloy, S. Daly, J. L. Mills et al., "Thermolabile variant of 5,10-methylenetetrahydrofolate reductase associated with low red-cell folates: implications for folate intake recommendations," The Lancet, vol. 349, no. 9065, pp. 1591-1593, 1997. 
[27] A. Reif, B. Pfuhlmann, and K. P. Lesch, "Homocysteinemia as well as methylenetetrahydrofolate reductase polymorphism are associated with affective psychoses," Progress in NeuroPsychopharmacology and Biological Psychiatry, vol. 29, no. 7, pp. 1162-1168, 2005.

[28] G. A. Nevo, S. Meged, B. A. Sela, A. Hanoch-Levi, R. Hershko, and A. Weizman, "Homocysteine levels in adolescent schizophrenia patients," European Neuropsychopharmacology, vol. 16, no. 8, pp. 588-591, 2006. 


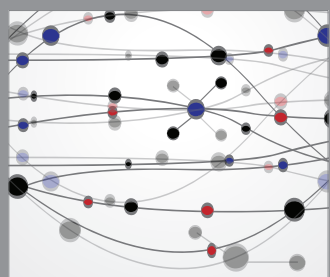

The Scientific World Journal
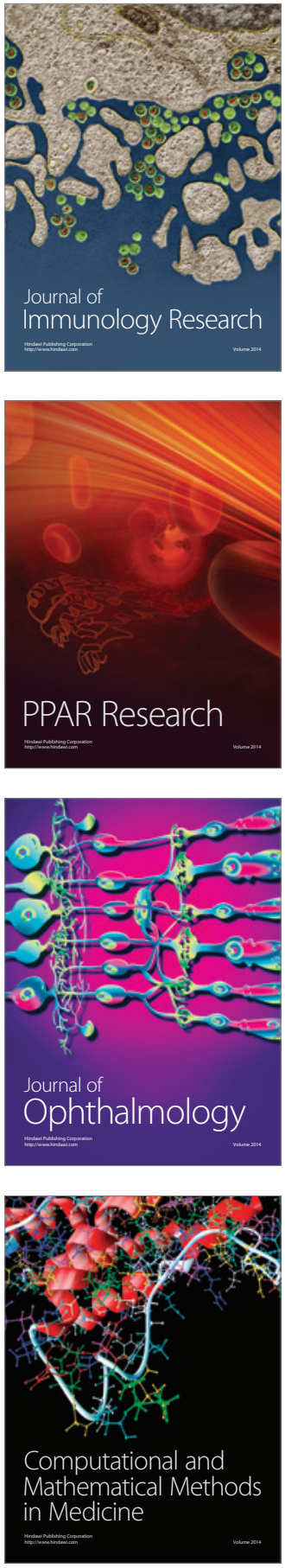

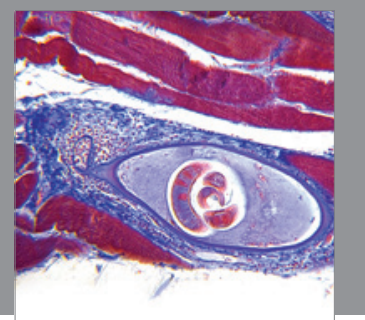

Gastroenterology

Research and Practice
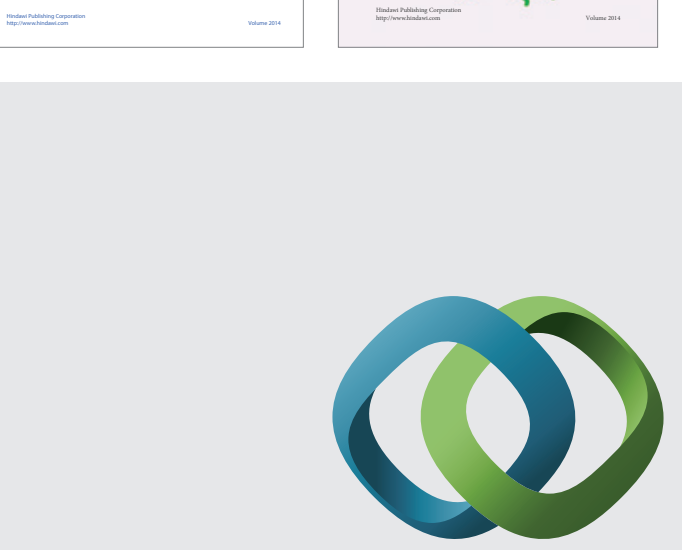

\section{Hindawi}

Submit your manuscripts at

http://www.hindawi.com
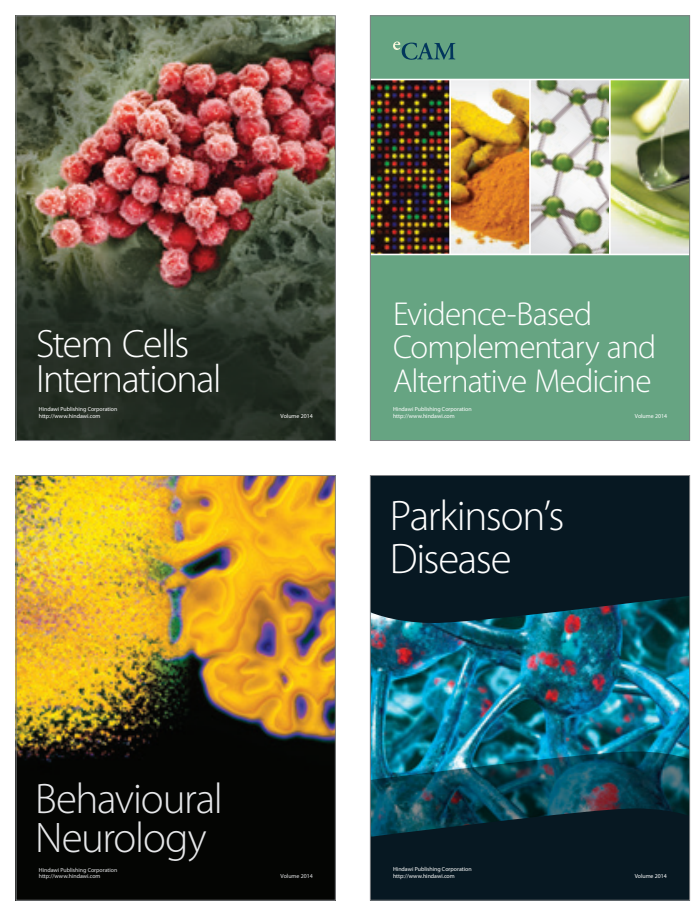

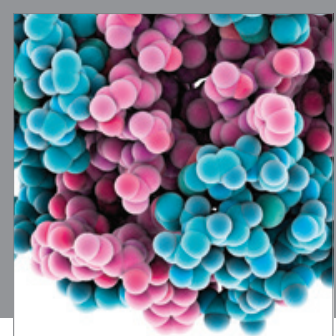

Journal of
Diabetes Research

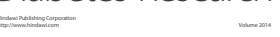

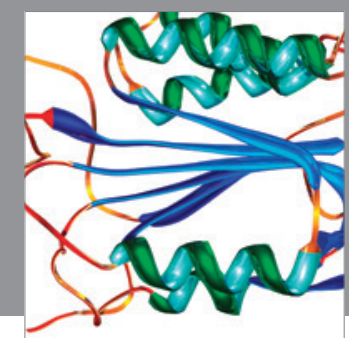

Disease Markers
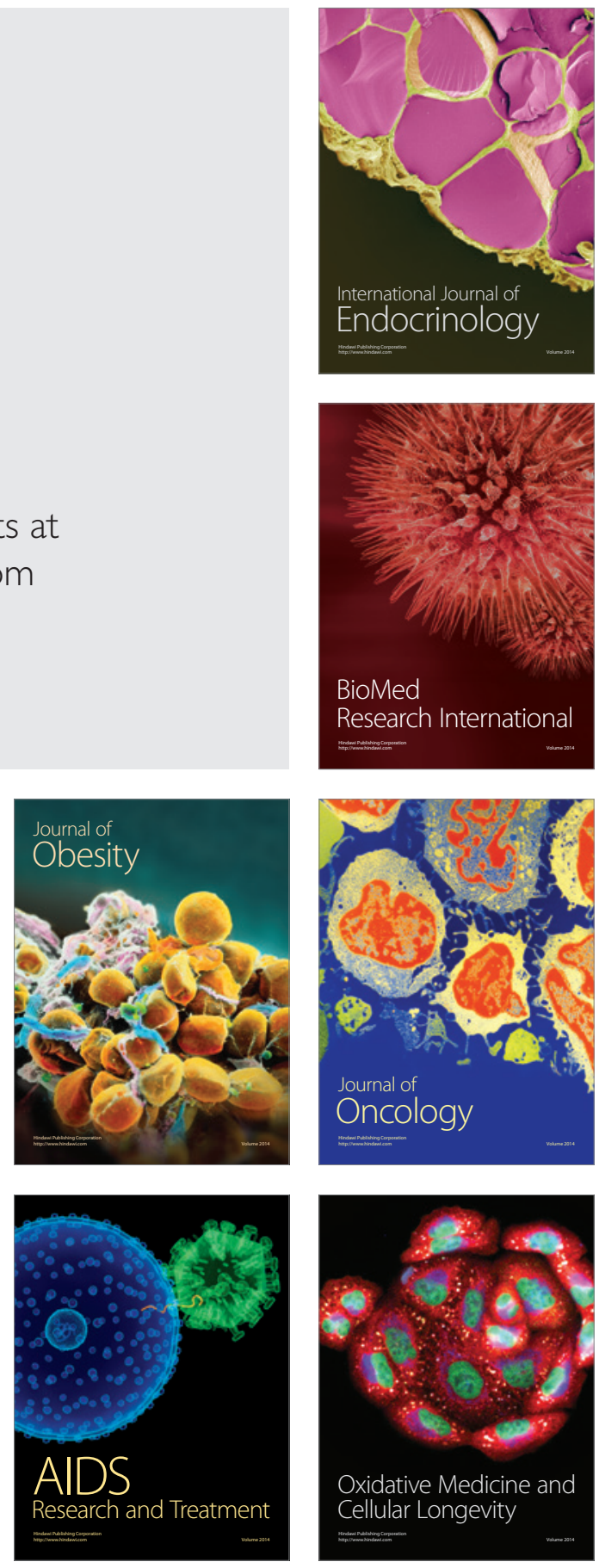